\title{
Redescription of Alopecosa krynickii (Thorell, 1875) (Aranei: Lycosidae) from the Crimea
}

\author{
Переописание Alopecosa krynickii (Thorell, 1875) \\ (Aranei: Lycosidae) из Крыма
}

\author{
D.V. Logunov \\ A.B. Аогунов \\ The Manchester Museum, The University of Manchester, Oxford Road, Manchester M13 9PL, UK. E-mail: dpavuk@ngs.ru
}

KEY WORDS: Ukraine, Crimea, spiders, Aranei, Lycosidae, Alopecosa.

КЛЮЧЕВЫЕ СЛОВА: Украина, Крым, пауки, Aranei, Lycosidae, Alopecosa.

\begin{abstract}
The paper presents a redescription, diagnosis and brief taxonomic notes on a poorly known wolf spider, Alopecosa krynickii (Thorell, 1875), comb.n., ex. Tarentula $\left(\bigcirc^{7}\right)$, from the Crimea.
\end{abstract}

РЕЗЮМЕ. Статья содержит переописание, диагноз и краткие таксономические заметки о малоизвестном виде пауков-волков, Alopecosa krynickii (Thorell, 1875), comb.n., ex. Tarentula $\left({ }^{7}\right)$, из Крымa.

\section{Introduction}

Alopecosa Simon, 1885 is a large genus of wolf spiders containing more than 160 named species worldwide [Platnick, 2013], of which many species remain known from the original descriptions only. The aim of the present work is to redescribe the male holotype of Tarentula krynickii Thorell, 1875, one of the least known south European species of wolf spiders, and to justify a transfer of this species to genus Alopecosa.

The male holotype is deposited in the Finnish $\mathrm{Mu}-$ seum of Natural History, University of Heslinki, Finland (FMNH; curator: Dr P. Cardoso). The terminology and format of description follow Logunov [2010]. Abbreviations used in the text: AME - anterior median eye, ALE - anterior lateral eye, Fm - femur, MA median apophysis, $\mathrm{Mt}$ - metatarsus, PME - posterior median eye, PLE - posterior lateral eye, $\mathrm{Pt}$ patella, $\mathrm{Tb}$ - tibia, $\mathrm{Tr}$ - tarsus. The sequence of leg segments in measurement data is as follows: $\mathrm{Fm}+\mathrm{Pt}+$ $\mathrm{Tb}+\mathrm{Mt}+\mathrm{Tr}$ (total). All measurements are in $\mathrm{mm}$.

\section{Description}

\section{Alopecosa krynickii (Thorell, 1875), comb.n.} Figs 1-7.

Tarentula krynickii Thorell, 1875a: 104 (D $\left.{ }^{7}\right)$. Tarentula krynickii Thorell, 1875b: 157 (D ${ }^{\text {T') }}$.
Avicosa krynickii: Roewer, 1955: 234.

Schizocosa krynickii: Helsingen, 2013: www; Kovblyuk, 2003: 235; Mikhailov, 2013: 131; Nentwig et al., 2013: www; Platnick, 2013: www.

TYPE. Male holotype (FMNH) from Simferopol, the Crimea, Ukraine: "Tarentula Krynickii Thor. / Sympheropol, Willa Steven. / 18.XI.1860, Tauria no. 62 / [Eut. Ettiketti no.307]"; details of the original data label are given on Fig. 3.

DIAGNOSIS. Alopecosa krynickii seems to belong to the striatipes species group [sensu Lugetti \& Tongiorgi, 1969] and is similar to A. taeniopus (Kulczyński, 1895) and A. beckeri (Thorell, 1875); see Nadolny \& Kovblyuk [2010] for detailed descriptions and a comparison of both species. A. krynickii differs from both these species, as well as from all other Alopecosa species known to me, by the unique shape of the median apophysis that has a wide, spoon-shaped lateral extension bent ventrad (Figs 4-5). A more detailed diagnosis of this species will be possible, when more male specimens and also females are collected. To date, the species remains known from the male holotype only.

DESCRIPTION. MALE (holotype). Carapace 7.35 long, 5.05 wide. Eye sizes and interdistances (Fig. 7): AME 0.35, ALE 0.26, PME 0.78, PLE 0.63, AMEAME 0.20, AME-ALE 0.10, PME-PME 0.53, PLEPLE 1.45. Width of anterior eye row 1.55 , second row 1.93 , third row 2.15. Clypeus height 0.19 , chelicera length 3.20. Abdomen 7.00 long, 4.00 wide. Length of leg segments: I $5.90+2.50+4.40+4.80+2.90$ (20.50); II $5.45+2.40+4.10+4.65+2.90(19.50)$; III $4.90+2.35+3.50+4.60+2.60$ (17.95); IV $6.40+$ $2.70+4.75+6.40+3.20(23.45)$. Leg formula: IV, I, II, III. Coloration (Figs 1-2), the specimen is visibly faded. Carapace yellowish orange, covered with white and brown hairs. Sternum yellow, densely covered with brown hairs. Maxillae and labium orange, with white apices. Chelicerae light, yellowish brown. Abdomen: dorsum and sides yellowish orange, with no pattern and with poorly marked cardiac mark (Fig. 1, but the specimen is faded!); venter dark brown and densely 


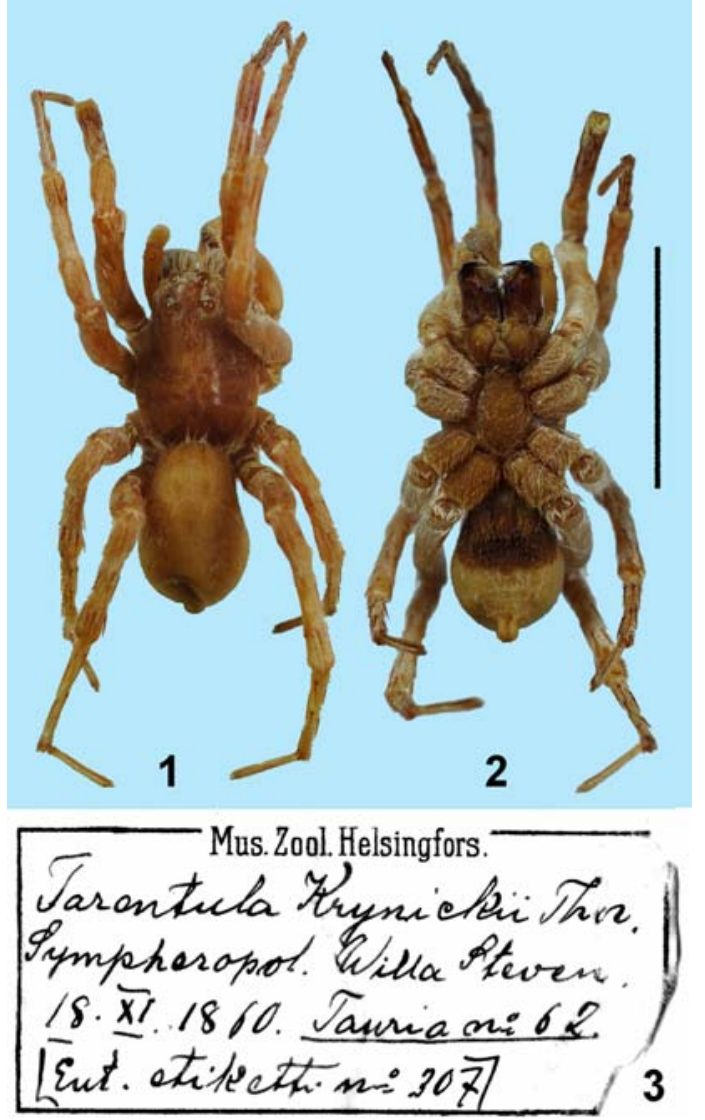

Figs 1-3. General appearance (1-2) and data label (3) of the $\sigma^{7}$ holotype Alopecosa krynickii (Thorell, 1875): 1 - dorsal view; 2 ventral view; 3 - data label. Scale bar: $10 \mathrm{~mm}$.

Рис. 1-3. Общий вид (1-2) и этикетка (3) голотипа О7 Alopecosa krynickii (Thorell, 1875): 1 - вид сверху; 2 - вид снизу; 3 - этикетка. Scale bar: 10 мм.

covered with brown hairs in its anterior half, and yellowish orange in its posterior half (Fig. 2). Book-lung covers yellow, densely covered with brown hairs. Spinnerets yellow. All legs yellowish orange, covered with white hairs; tibiae and metatarsi I darker - brownish. Palpal structure as in Figs 4-5: the embolus seems to be narrow, it is almost invisible behind the median apophysis; the median apophysis is wide and elongated laterad, with the spoon-shaped lateral extension having a tooth directed ventrad; the palea with a poorly marked pointed prominence; the functional conductor is small and poorly visible.

FEMALE unknown.

DISTRIBUTION. Ukraine, the Crimea: the type locality only.

\section{Taxonomic notes}

In Platnick [2013] and in a number of regional catalogues [e.g., Kovblyuk, 2003; Mikhailov, 2013; etc.] Alopecosa krynickii is listed under the genus Schizocosa Chamberlin, 1904, apparently resulting from the fact that this species was assigned by Roewer [1955] to the genus Avicosa Chamberlin et Ivie, 1942 which was later synonymized with Schizocosa [Dondale \& Redner, 1978: 146]. However, A. krynickii possesses none of the two main diagnostic characters of Schizocosa males (see Dondale \& Redner [1978: 147, figs 126; 1990: 54]): viz., the embolus with broad par pendula and distally bent intromittent part and the scalelike terminal apophysis. Besides, according to Dondale \& Redner [1990], the genus Schizocosa containing 21 valid species is restricted to North America. Thus, the assignment of $A$. krynickii to the genus Schizocosa seems to have been unjustified.

In his original description, Thorell [1875b: 158] compared A. krynickii with Trochosa dimidiata Thorell 1875 , the type species of the poorly diagnosed genus Mustelicosa Roewer, 1960 [Marusik \& Buchar, 2004: figs 1-8; Platnick, 2013]. Indeed, A. krynickii has got the same leg formula (IV, I, II, III) and two retromarginal teeth on the chelicerae (Fig. 6) [cf. Roewer, 1960: 917]. However, both characters seem to be shared by a number of Alopecosa-like genera of wolf spiders and thus seem to be of little taxonomic value. The main difference between the males of $A$. krynickii and $M$. dimidiata lies in the conformation of their palps, particularly in the presence of well-developed, embolus-like synemolus in $M$. dimidiata and its absence in A. krynickii. The embolus-like structure on the Fig. 1 in Marusik \& Buchar [2004: 154] and Fig. 22.10 in Marusik \& Kovblyuk [2011: 185] is actually the synembolus [sensu Logunov, 2010]. The real, rather thin embolus of $M$. dimidiata is hidden behind the median apophysis and lies below the synembolus (not shown by Marusik \& Buchar [2004]). The taxonomic status of Mustelicosa or an analysis of the detailed conformation of copulatory organs of its species are outside the scope of this paper. It is worth mentioning though that the presence of synembolus is a reliable diagnostic character to separate Mustelicosa from Alopecosa that warrants its independent taxonomic status, however the scope of the former genus needs further thorough study. For the present discussion it is enough to just stress that, in my opinion, A. krynickii cannot be assigned to Mustelicosa.

To conclude the discussion, A. krynickii shares all the man diagnostic characters of true Alopecosa [sensu Dondale \& Redner, 1990]: viz, medium body size; the presence of a cardiac mark on the abdomen (Fig. 1), which is visibly faded in the holotype; cheliceral retromargin with two teeth (Fig. 6); femur I with a prolateral spine; the angular median apophysis (Figs 4-5); the palea with a poorly marked pointed prominence (Fig. 4). Therefore, a transfer of Tarentula krynickii to the genus Alopecosa, as already proposed above, seems to be well justified. Finally, the genus Schizocosa should be removed from the list of European Lycosidae [cf. Helsingen, 2013; Nentwig et al., 2013].

ACKNOWLEDGEMENTS. I am most grateful to the following colleagues who helped me during preparation of the present work: Phillip Rispin (Manchester, UK) for mak- 

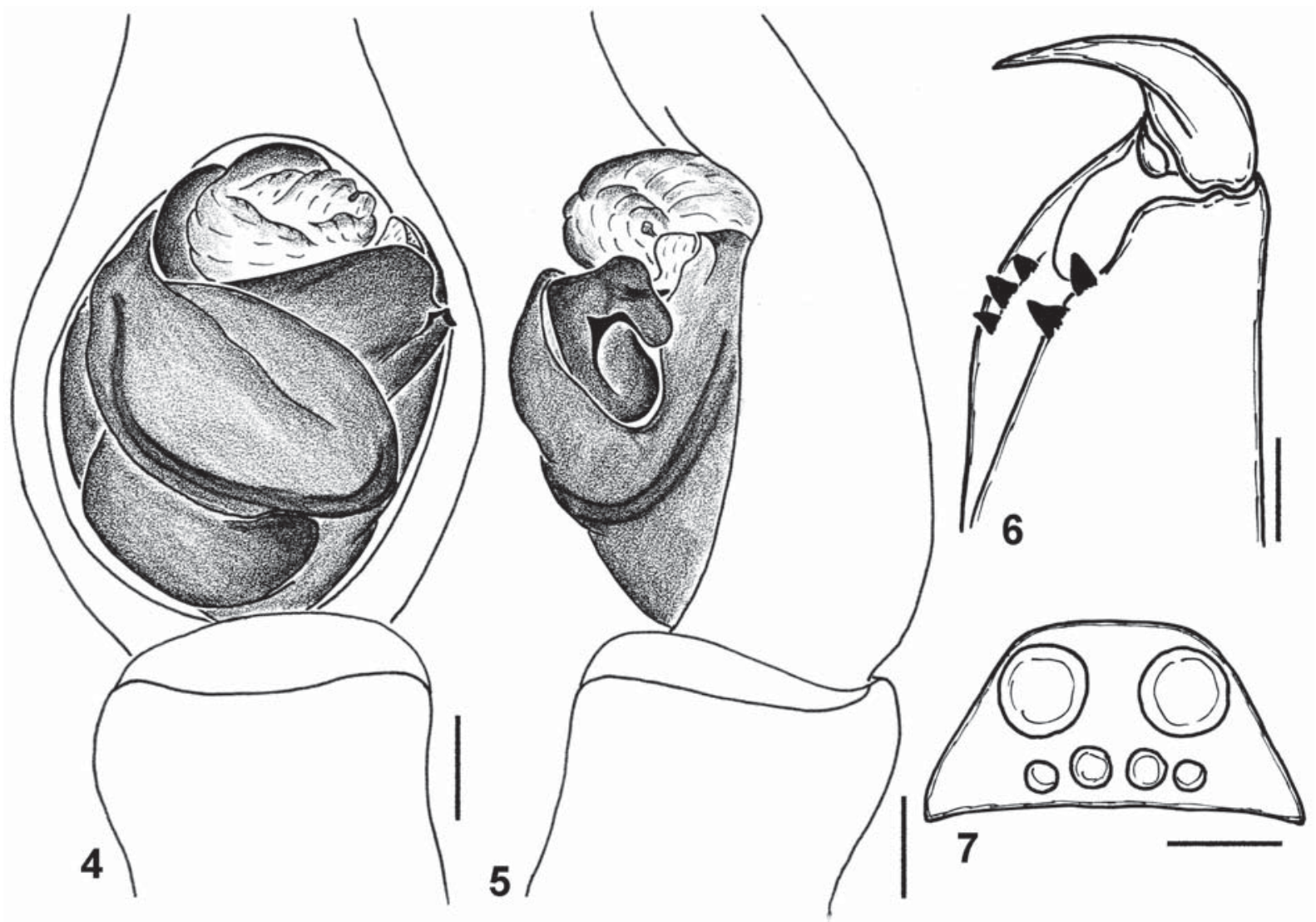

Figs 4-7. Copulatory organs and somatic characters of the $0^{7}$ holotype Alopecosa krynickii (Thorell, 1875): 4 - male palp, ventral view; 5 - ditto, retrolateral view; 6- chelicera, ventral view; 7 - eye field, frontal view. Scale bars: (4-6) $0.25 \mathrm{~mm}$, (7) $0.5 \mathrm{~mm}$.

Рис. 4-7. Копулятивные органы и соматические признаки голотипа О7 Alopecosa krynickii (Thorell, 1875): 4 — пальпа самца, вид снизу; 5 - тоже, вид сбоку; 6 - хелицера, вид снизу; 8 - глазное поле, вид спереди. Масштаб: (4-6) 0,25 мм, (7) 0,5 мм.

ing the digital images of the general appearance of the studied specimen, Yuri Marusik (Magadan, Russia), Mykola Kovblyuk (Simferopol, Ukraine) and Anton Nadolny (Kiev, Ukraine) for their comments on the taxonomic status of Alopecosa krynickii, and finally Jon Cooter (Oxford, UK) for his kind linguistic help.

\section{References}

Dondale C.D., Redner J.H. 1978. Revision of the Nearctic wolf spider genus Schizocosa (Araneida: Lycosidae) // Can. Ent. Vol.110. P.143-181.

Dondale C.D., Redner J.H. 1990. The wolf spiders, nurseryweb spiders, and lynx spiders of Canada and Alaska. The Insects and arachnids of Canada, part 17. Ottawa, Canada, 383 pp.

Helsdingen van, P. 2013. Fauna Europaea: Araneae. Fauna Europaea version 2.6.2, online at: http://www.faunaeur.org (accessed 18 October 2013).

Kovblyuk M.M. 2003. [Catalogue of the Crimean spiders (Arachnida: Aranei)] // Voprosy Razvitiya Kryma. No.15. P.211-262 [in Russian, with English and Ukrainian summaries].

Logunov D.V. 2010. On new central Asian genus and species of wolf spiders (Araneae: Lycosidae) exhibiting a pronounced sexual size dimorphism // Proc. Zool. Inst. RAS. Vol.314. No.3. P.233-263.
Lugetti G., Tongiorgi P. 1969. Ricerche sul genere Alopecosa Simon (Araneae-Lycosidae) // Atti della Societa Toscana di Scienze Naturali, Memorie, Serie B. Vol.76. P.1-100.

Marusik Yu.M., Buchar J. 2004. A survey of the east Palearctic Lycosidae (Aranei). 3. On the wolf spiders collected in Mongolia by Z. Kaszab in 1966-1968 // Arthropoda Selecta. Vol.12. No.2. P.149-158.

Marusik Yu.M., Kovblyuk M.M. 2011. [Spiders (Arachnida, Aranei) of Siberia and Russian Far East]. Moscow: KMK Scientific Press. 344 p. [in Russian]

Mikhailov K.G. 2013. The spiders (Arachnida: Aranei) of Russia and adjacent countries: a non-annotated checklist // Arthropoda Selecta. Supplement No.3. Moscow: KMK Sci. Press. 260 p.

Nadolny A.A., Kovblyuk M.M. 2010. On two closely related wolf spider species Alopecosa beckeri (Thorell, 1875) and A. taeniopus (Kulczyński, 1895) (Aranei: Lycosidae) // Arthropoda Selecta. Vol.19. No.4. P.237-247.

Nentwig W., Blick T., Gloor D., Hänggi A., Kropf C. 2013. Spiders of Europe (version 3.2013), online at: www.araneae.unibe.ch (accessed 18 October 2013).

Platnick N.I. 2013. The world spider catalog, version 13.5. American Museum of Natural History, online at: http://research.amnh. org/entomology/spiders/catalog/index.html (accessed 18 October 2013).

Roewer C.F. 1955. Katalog der Araneae von 1758 bis 1940, bzw. 1954. Bruxelles. Bd.2. $1751 \mathrm{~S}$

Roewer C.F. 1960. Araneae Lycosaeformia II (Lycosidae) (Fortsetzung und Schluss) // Explor. Parc natn. Upemba Miss. G. F. de Witte. Bd.55. S.519-1040. 
Thorell T. 1875a. Verzeichniss südrussischer Spinnen // Horae Soc. ent. Ross. Vol.11. P.39-122.

Thorell T. 1875b. Descriptions of several European and North African spiders // Kongl. Svenska. Vet.-Akad. Handl. Vol.13. No.5. P.1-203.

Responsible editor K.G. Mikhailov 